\title{
DATA, THEIR RELEVANCE TO COMPETITION AND SEARCH ENGINES
}

\author{
by \\ RASTISLAV FUNTA*
}

\begin{abstract}
A special feature of digital markets and digital business models is the high importance of (user) data. The control and the ability to analyze large amounts of data (big data) can create competitive advantage. Thus, the importance of data for the economic success of companies should be given more consideration in competition law proceedings. In search services competition, the quality factor plays a decisive role, since the expected quality of the search results determines which search engine will be used by users. Since search engines can influence the retrievability of web pages for users, preference of own search services in the web index may constitute an abusive behavior of a dominant search engine. The purpose of this paper is to provide answers on questions, among other, whether a regulation aimed at preventing abuses is necessary or whether an obligation to publish the search algorithm may be advocated.
\end{abstract}

\section{KEY WORDS}

Competition, Data, Digital Markets, GDPR, Market Shares, Search Engine

\section{INTRODUCTION}

The control and the ability to analyze large amounts of data, which are often in exclusive possession of individual companies, can create decisive competitive advantage. These data are used e.g. for personalization and for

rastislav.funta@vsdanubius.sk, Associate professor of European Union law at Janko Jesensky Faculty of Law, Danubius University, Sladkovičovo, Slovak Republic. 
further development of services and products. In addition, they are used in the online advertising market to display targeted ads. The increase use of data can in principle lead to welfare gains. Consumers benefit from new products as well as from the personalization of services. For example, companies can optimize their warehousing or target advertising campaigns on internet more precisely. In other cases, the increase in collection of data can also lead to welfare losses. Affected may be, in particular, consumers who are not sufficiently informed about the use of their data. The collection and economic exploitation of data is subject to restrictions arising from data protection law. ${ }^{1}$ At present, it is unclear whether and to what extent the individual also has the right to decide on a possible asset of personal data and thus on economic exploitation and utilization beyond their fundamental right of defense and the associated protection claim. First of all, from competition policy perspective, an approximation of national data protection standards would be advocated since the strictness of data protection law can influence the possibilities for collecting and analyzing large databases and thus the success of competing companies. In order to avoid distortions of competition and to achieve a competitive level playing field, the adoption of the European General Data Protection Regulation (GDPR) is to be welcomed. ${ }^{2}$ Due to the often asymmetric distribution of information between companies and consumers it seems sensible to strengthen the position of consumers. In order to give users better control over their data, legislation may in certain cases require mandatory consent of users in regards to collection and use of their data (opt-in). However, potential negative effects on individual business models, such as online advertising, should be taken into account. In addition, the introduction of the right to data portability provided by the GDPR make sense from competition perspective in order to mitigate unwanted lock-in effects and to give internet users more control over the use of their data.

Search engines represent a significant area of the digital economy. Since its beginnings in the 1990s, online search has become one of the internet's most profitable business areas. Given the abundance of information on the internet, search engines play a key role for both internet users seeking information and website owners whose content is easier to find

1 Daňko, M., Žárská, P. (2019) Data protection vs. Intellectual property. Počítačové právo, UI, ochrana údajov a najväčšie technologické trendy. Brno: MSD, 2019, p. 127 and follows.

2 Funta, R. (2019) Úvod do počítačového práva práva [Introduction into computer law]. Brno: MSD, 2019 , p. 121 and follows. 
through search engines. Search engines thus make an important contribution to reducing transaction costs, for example in the form of search costs for users and advertising costs for the content providers (intermediation service). ${ }^{3}$ In regards to search services, the quality factor plays a decisive role, since the expected quality of the search results determines which search engine will be used. The more data a search provider has, the better he can tailor search results and search advertising to user interests. However, changing the search provider is relatively easy and possible at no extra cost (disciplining effect on search engine operators). Since search engines can influence the discoverability of web pages for users, preference of own search services may constitute an abusive behavior of a dominant search engine. However, it has to be taken into account that search engines must be allowed discretion when creating the web index. In addition, it can be problematic when third-party content is used regardless of exploitation rights (so-called scraping). From our point of view it does not make sense to regulate the search algorithm to ensure search neutrality for several reasons. State control of search algorithm, if technically feasible at all, would require substantial public funding. The proof of an abusive design of the algorithm would be also difficult. Also an obligation to publish the search algorithm is not to be advocated. If the algorithm would be publicly known, web site operators would be able to optimize their pages to significantly reduce their relevance for displaying search results. Finally, an obligation to disclose or split the web index with competing search engines is not to be endorsed as it would eliminate incentives to create and constantly update the index.

\section{DATA AND THEIR RELEVANCE FOR COMPETITION}

A typical characteristic of many business models in the digital economy is the collection and exploitation of data. Some data are already regarded as the new currency of the digital age. Unlike many other commodities, data can always be used over and over again (they are fundamentally nonrival in their use). However, they are often in exclusive possession of individual companies that decide about their use. Controlling and analyzing large volumes of data can become a key competitive advantage. The following part will provide a brief overview of the nature and extent

3 Jones, A., SUFRINSuffrin, B. (2016) EU Competition Law: Text, Cases, and Materials. Oxford: Oxford University Press, 2016, p. 23. 
of data collection and exploitation and their relevance to digital business models.

\subsection{MEANING OF BIG DATA}

A topic that is highly discussed is the extensive collection, storage and linking of data ("Big Data") ${ }^{4}$ in the course of increasing digitization. When defining "Big Data", the so-called Volume, Variety and Velocity phenomenon is usually referred to. These describe the algorithmic analysis of particularly large amounts of data (volume) from various sources and formats (variety) in the highest possible velocity (velocity). The importance of large amounts of data can explain why some companies save data without previously defined purpose, in order to analyze it at a later date. Overall, it should be noted that the increased analysis of data can lead to an individualization of products and prices, which may be beneficial ${ }^{5}$ for individual users but disadvantageous for others. But the collection, processing and analysis of personal data also raise socio-political questions, such as the extent to which the use of personal data or a price differentiation according to individual characteristics of the users should be permitted.

\subsection{PURPOSES OF DATA COLLECTION}

Companies usually pursue very specific goals when collecting data on the Internet. Depending on the business model, ${ }^{6}$ different interests are in the foreground. In principle, there is a difference between providers of online services and advertising companies, with some companies being active in both areas. Online services allow the collection of data and tracking of Internet users inside and outside of their own services. They can use these insights to continuously optimize and personalize their products and services. In addition, they can derive potential from such data and, based on this, develop new products and services with particular relevance to users. The ability to collect and analyze data is thus a key driver of the innovative strength of these companies. The ability to optimize services through data is particularly evident in the form of increasing personalization. Examples of such personalization can be found in some

\footnotetext{
4 Funta, R. (2018) „Big Data“ from competition law point of view. Justičná revue, č. 8-9, 2018, pp. 902-915.

5 Furman, J. (2019) Unlocking digital competition. Report of the Digital Competition Expert Panel. London: HM Treasury, p. 54.

6 Peráček, T. (2020) The perspectives of European society and the European cooperative as a form of entrepreneurship in the context of the impact of European economic policy. Online Journal Modelling the New Europe, (34), pp. 38-56.
} 
online services, e.g. online shops provide product recommendations based on previously purchased or respected products; search engines generate hit lists based on search history and location of users, and display social content tailored to the interests of their members. For companies, personalization can also result in customer loyalty that is advantageous to them. From a competition policy perspective, such a high level of customer loyalty is only problematic if it leads to lock-in effects, for example because users have only limited possibilities to take data to another online service (lack of data portability). ${ }^{7}$ The extensive data use can lead to a disadvantage of individual user groups. In this context, the possibility of price differentiation in online shops can be mentioned by capturing and combining different data, which enable companies to draw conclusions about the willingness to pay of individual consumers or consumer groups through personalized prices. The phenomenon of price differentiation is not new in itself. For example, companies in the transport sector already have different prices depending on the time, occupancy or booking period. Price differentiation is an integral part of the revenue management of many companies. What is new, however, is the possibility of personalized price differentiation on the Internet, which is based on the observed characteristics or habits of consumers. From an economic point of view, such a price differentiation can be welfare enhancing. However, new social and consumer protection issues may arise as consumers, in particular, who are less sensitive to the use of their data, could be disadvantaged.

The collection and analysis of data is of high importance to companies active in the field of online advertising. This include on the one hand companies specialized in online advertising that have no direct contact with the Internet user. On the other hand, vertically integrated and diversified companies such as Google offer services for both Internet users (search engine, social network, etc.) and advertisers (advertising networks, etc.). ${ }^{8}$ While in the former case data collection is performed, in particular, by means of cookies and other tracking technologies that enable cross-website tracking of Internet users, in the latter case user data can be collected through the interaction between the user and the online service.

7 Hudecová, I., Cyprichová, A., Makatura, I. a kol. (2018) Nariadenie o ochrane fyzických osôb pri spracúvaní osobných údajov - Vel'ký komentár. [Regulation on the protection of individuals with regard to the processing of personal data-Commentary], Bratislava: Eurokódex, p. 260.

8 Funta, R. (2018) Google Android from legal perspective. Justičná revue, č. 4, pp. 423-437. 
Since targeted advertising increases the consumer's likelihood of buying, advertisers are interested in such ads. The placement of less relevant advertising due to the reduced use of data by the advertising companies could also have a negative impact on the provision of such free offers.

\subsection{LEGAL FRAMEWORK OF DATA COLLECTION AND EXPLOITATION}

The collection and economic exploitation of data is subject to restrictions arising from data protection law. Data protection law provides for fundamental rights protection, in particular the protection of individuals through the right to privacy. This right is an outflow of human dignity and freedom of action. It protects any behavior that has relevance to personality development, especially in terms of self-determination (including the right to informational self-determination), privacy and self-expression. Additional protection for non-personal data results from the fact that the integrity and confidentiality of information technology systems can also be relevant to fundamental rights. ${ }^{9}$ Data protection law has its origin in a constitutional right of defense against the state. However, it goes beyond this in that it also provides protection against the use of data in an economic context. From the point of view of competition policy, the definition of data protection by the legislator can be accepted in the given form as long as it does not result in an unjustified impairment of competition. ${ }^{10}$ Data protection law contains a number of principles which must be taken into account in the further competitive economic and legal assessment. In particular, data collection, processing or use of personal data is only permitted on the basis of a legal basis or if the data subject has provided consent. The storage, modification or use of personal data is only allowed for specific purposes. The European General Data Protection Regulation (GDPR) further develop and supplement these principles, not least through more effective information requirements for data processing.

\subsection{COMPETITION POLICY IMPLICATIONS}

The previous statements have shown that the collection of extensive data and their evaluation for many service providers on the Internet are part

\footnotetext{
Svák, J. (2011) Ochrana l'udských práv [Protection of human rights]. I. Zväzok, Bratislava: Eurokódex, p. 4.

10 Svoboda, P., Munková, J., Kindl, J. (2012) Soutěžní právo [Competition law]. 2. vydání, Praha: C.H.Beck, p. 127.
} 
of everyday life. ${ }^{11}$ At the same time, from the increased use of data will benefit a large number of Internet users in some cases through free and personalized services. However, due to the increased use of personal data, there is a need for action from a competition policy perspective.

\subsubsection{ALIGNMENT AND IMPROVED ENFORCEMENT OF PRIVACY STANDARDS}

The automatic transmission of data (e.g. through the use of cookies) repeatedly encounters concerns of privacy advocates. The fear behind it is that detailed user profiles that include not only buying behavior but also political, religious, or sexual preferences will be created. Against this background, it is first and foremost the task of the data protection law to create clear regulations for the digital world, ${ }^{12}$ which concretely show which data are collected and to what extent they can be evaluated. From a competition policy point of view, it should be noted that the relative severity of data protection law can have an impact on the competitive and thus also the innovative capacity of companies. In principle, it can be assumed that companies will use the opportunities they have been granted to collect and process data. However, this does not mean that, from a competition policy perspective, lowering data protection standards would be appropriate. ${ }^{13}$ An approximation of data protection rules should be sought in principle, ideally at global level, but at least at European level, in order to create a level playing field in this area and to avoid distortions of competition resulting from different data protection standards.

\subsubsection{STRENGTHENING CONSUMER RIGHTS}

A fundamental problem of the extensive collection and exploitation of private data on the Internet is the asymmetrical distribution of information between providers and consumers. For many Internet users, it is usually difficult to understand which companies collect which data and evaluate it and whether such data are linked to other data. In addition, many users may not be aware of the commercial value of their data. In principle, however, there are already many possibilities to limit the transmission of certain data to companies. This includes, for example,

11 Plavčan, P.; Funta, R. (2020) Some Economic Characteristics of Internet Platforms. Danube: Law, Economics and Social Issues Review. No. 2. pp. 156-167.

12 Crémer, J., de Montjoye, Y-A., Schweitzer, H. (2019) Competition Policy for the Digital Era. Brussels: Directorate-General for Competition. p. 39 and follows.

13 Karas, V., Králik, A. (2012) Právo Európskej únie [European union law]. 1. vydanie, Bratislava: C.H.Beck, p. 409. 
the regular deletion of cookies and other data stored in the web browser. In addition, the creation of certain types of cookies can generally be prohibited in the browser settings. Such settings are basically relatively easy to make, but not known to all Internet users. In addition to these possibilities, some companies also offer the option of having records deletion option. In addition, to allow users to better control their data, legislation might consider increasing use of the opt-in approach. According to this, companies would have to obtain explicit consent from users for the storage and evaluation of (personal) data. From a competition policy point of view, however, it should be noted that compulsory user consent to the collection and analysis of its data could give preference to certain business models. On the other hand, it would be possible for advertising companies that are not in direct contact with the user to collect data by anonymous tracking.

Another approach to strengthen consumer rights is the right to data portability as stated in the European General Data Protection Regulation (GDPR). ${ }^{14}$ This right obliges companies to facilitate the transfer of stored customer data to other companies. The competitive effects of such a right largely depend on its concrete form. In case this includes content data which the user has deliberately made available to the company, it could contribute to the generally welcome weakening of possible lock-in effects from a competitive point of view.

\subsubsection{GREATER CONSIDERATION OF DATA IN COMPETITION LAW REVIEWS}

The question is whether the possibility of access to data by companies should be taken more into account when evaluating competition law issues. This could be justified, in particular, by the fact that, as presented in the context of this chapter, data becomes an increasingly competitive factor for businesses and can be regarded as a kind of "commodity" for digital business models. As shown, data is relevant not only for the purpose of more targeted placement of online advertising, but also for the continuous development and redevelopment of online services. From a competition economics point of view, greater consideration of data,

\footnotetext{
14 Mesarčík, M. (2020) Ochrana osobných údajov [Personal data protection]. Bratislava: C..H.Beck, p. 1 and follows; Míšek, J. (2020) Moderní regulatorní metody ochrany osobních údajů. [Modern regulatory methods of personal data protection]. 1. vyd. Brno: Masarykova univerzita, p. 1 and follows.
} 
in particular in the context of merger control, ${ }^{15}$ seems necessary, since newly established Internet services with so far only low turnovers, but possibly very valuable data sets, could have been bought by competitors. The need to recognize aspects of data concentration as part of the merger investigation has been recognized by the competition authorities. For example, in the Facebook/WhatsApp case, ${ }^{16}$ the European Commission has examined the impact of the merger on the possibility of accessing the data for subsequent use in the advertising market. The European Commission found that there is no problematic concentration of advertising-relevant data on Facebook, as numerous other companies also extensively collect data.

\section{SEARCH ENGINES}

Search engines play a central role not only for Internet users who are looking for information, or website operators, whose content is easier to find by search engines, but also for online advertisers, who targeted search advertising. Since its beginnings in the 1990s, the online search market has become the Internet's highest-revenue market.

\subsection{ABOUT THE FUNCTIONALITY OF SEARCH ENGINES}

The basic function of search engine is to make it easier for users to find information on the Internet. Given the amount of information available on internet, search engines play a key role as information intermediaries. Since search services are usually offered free of charge, search services compete mainly in regards to their quality. This is typically measured by the relevance of the search results to the user. Other quality factors include the speed at which search results are delivered and the design of the user interface. Most general search engines rely on a simple interface that allows us to enter search terms in a search field. The search engine Yahoo! in contrast, relies on a portal model where users already provide information prior to a possible search request. Google, Bing or Yahoo! are also referred to as general or horizontal search engines because they provide search results for all types of search queries. Relevant web pages are displayed to the user as so-called organic or natural search hits on the web page. In addition to the display organic search results,

15 Borchardt, K. D. (2010) Die Rechtlichen Grundlagen der Europäischen Union. 4. Auflage, Heidelberg: C. F. Müller, p. 536.

16 Funta, R. (2018) Facebook from competition law perspective. Justičná revue, č. 1, pp. 1-16. 
advertising-based search engines display search advertising. In addition to horizontal search engines, search queries such as images, videos or messages can also be viewed by specialized (vertical) search engines, which typically use a corresponding image, video or message index. In addition, there are other websites that allow search function in certain categories. For example, Amazon ${ }^{17}$ provides information about products and Facebook provides information about individuals.

\subsection{THE ECONOMIC IMPORTANCE OF SEARCH ENGINES}

As intermediaries, search engines play a central role in providing information on the Internet. The information search without technical tools would be very expensive and in many cases from the user's point of view hardly feasible, if not impossible. ${ }^{18}$ This is supported by the fact that there are simply too many websites on the Internet and the addresses of the websites (URL) are assigned unsystematic, as that a person could visit them without technical tools. Therefore, for a majority of Internet users, a typical online session starts with a search query on a search engine. Search queries can be divided into three categories from the user's perspective:

- Navigation-oriented queries, where a user searches for pages he already knows,

- Information-oriented inquiries where a user often informs himself about a topic through several consecutive searches and

- Transactional requests that are made with the goal of making a transaction.

From an economic point of view the great added value of search services is on the one hand to reduce transaction costs, such as in the form of search costs and advertising costs on the part of the content providers. Assuming that search results are displayed according to their relevance, this also increases general market transparency ${ }^{19}$ for users. Through the performance of the search engine, information can be found more efficient and transactions may be faster.

17 Funta, R. (2018) Amazon and antitrust enforcement. Justičná revue, č. 11, pp. 1215-1229.

18 Polčák, R. a kol. (2018) Právo informačních technologií [Information technology law]. Praha: Wolters Kluwer, p. 1 and follows.

19 For a broader view see also chapter 4.1 new rules for online platforms and search engines in the eu ("p2b regulation") below. 


\subsection{CONCENTRATION TENDENCIES IN MARKETS FOR SEARCH PLATFORMS}

Ad-supported search services operate on a three-way platform market where (1) the search engine users searching for content on the Internet (2) the content providers whose web pages are indexed by the search engine and (3) the advertisers who advertise the search, are merged. Depending on the subject of investigation, it may be legitimate to consider search engines as two-sided platforms.

\subsubsection{MARKET DEFINITION AND MARKET SHARES}

A competitive view of a market usually requires evaluation in order to determine market shares as an indicator of market concentration. ${ }^{20}$ Due to the versatility of search platforms, this can be done by looking at the individual platform sides. Each platform side must be separated according to product and geographical criteria and the shares on the respective platform side must be determined separately. The geographic delimitation of digital markets is often likely to be worldwide due to virtually nonexistent transport costs of digital products. ${ }^{21}$ In the case of search platforms, however, it must be assumed that, in many cases, the market definition due to linguistic and cultural differences has to be made along national borders. When assessing a high market share of a search platform, it should be borne in mind that it does not necessarily have to be a market failure that would require government intervention. In the following, it will be discussed which factors on the search engine market can influence a market concentration and to what extent market power is favored or possibly restricted.

\subsubsection{FACTORS THAT CONTRIBUTE TO MARKET CONCENTRATION AND MARKET DOMINANCE}

In the case of search platforms, there may be a lack of competition which could result in low quality search or high prices for advertisers. In the long term, a monopolist may lack incentives to create new innovative search services. In addition, market power can be used to gain competitive advantage through abusive behavior. ${ }^{22}$ In the following, therefore, it will be discussed which factors favor market concentration in the search engine

${ }^{20}$ Svoboda, P. (2010) Úvod do Evropského práva [Introduction into EU law]. 3. vydání, Praha: C.H.Beck, pp. 240-241.

21 Funta, R. (2019) Economic and Legal Features of Digital Markets. Danube Law and Economic review, Issue 2, p. 1 and follows. 
market and to what extent the possibility for market entry is thereby influenced. As with many other digital goods, in the case of search services, so-called economies of scale are expected to play an important role. Costeffective economies of scale generally occur when average costs decrease due to high fixed costs with increasing output. In the case of search engines, billions of dollars in fixed costs to be incurred, for example, for the creation of the web index, the development of the search algorithm and the construction of data centers. The extent to which a high volume is also a prerequisite for a successful market entry is a controversial topic. While it is argued on the one hand that data have become central to market success, on the other hand data are available in large quantities on the Internet. At this point, it is not possible to conclusively assess the extent to which data from sources other than the search engine represent suitable substitutes and the market access would be possible without access to historical data. In addition to economies of scale, network effects are also relevant, with a distinction being made between direct and indirect network effects. Direct network effects generally occur when the use of a service increases with the number of users in a group. From the seekers point of view, such network effects are not obvious at first, because unlike social networks, there is no direct interaction between search engines. The users of a search engine do not benefit directly from the use of the search engine by another seeker. For advertisers, it can be assumed that there are no positive direct network effects. Rather, it is to be expected that advertisers compete for advertising space and the attention of users. Likewise, no positive network effects are expected for content providers, as they are competing for user attention comparable to the group of advertisers. Indirect network effects are likely to occur by search engines on the side of advertisers, because the more users are linked to a search engine, the more attractive this is from the advertisers point of view. The quality of a search engine increases with its ability to display advertising as accurately as possible to a relevant consumer group. Negative indirect network effects between advertisers and search engine users may cause users decrease if too much advertising is used. A large number of users and

22 Funta, R., Nebeský, Š., Juriš, F. (2012) Európske právo [EU law]. Brno: Tribun EU, p. 385; Krausová, A. (2018) Abuse of market power in ICT sector. The Lawyer Quarterly, No. 1, pp. 75-81; Klimek, L. (2013) Effective Enforcement of Sanctions for Market Abuse in the EU: Introduction of Criminal Sanctions. Czech Yearbook of International Law, New York: Juris Publishing, p. 105. 
a corresponding increase in search advertising clicks are likely to have a positive impact on the search engine's ability to target advertising to customer groups with a corresponding buying interest. Both, the search engine through higher advertising revenue (economies of scale) and advertisers through higher sales will benefit. Another factor that can influence market concentration is the ability of a platform to expand its capacity. In the case of search engines, capacity for answering search queries and indexing web pages should be relatively easy to expand with the corresponding expansion of server capacities. Advertisers are most likely to think that the number of ads that can be displayed is limited by the amount of space available on the website. However, the ability of a search engine to display ads increases with the number of search queries. Specifically, this means that there are no limits to quickly gain high market shares due to capacity constraints. On the one hand, this can help search engine to quickly increase its market share. It can be summarized that the focus on search platforms is favored in particular by economies of scale and network effects. Both factors also ensure that market entry is more difficult and associated with correspondingly high investment costs.

\subsection{POTENTIAL COMPETITION PROBLEMS ON THE SEARCH PLATFORMS MARKETS}

In the following, possible competition problems on the search platforms markets are discussed, which result from the fact that search platforms on the one hand can influence access to websites and on the other hand develop their services by integrating new functions and search services. ${ }^{23}$

\subsubsection{SEARCH PLATFORMS}

Because of their role as intermediaries in the search for information, horizontal search engines in general and in particular the search engine Google are often referred to as the "gatekeeper". Thus, gate keeping is understood as a process of filtering and editing information that determines what content reaches or does not affect the reader, thereby influencing public opinion. ${ }^{24}$ Search engines also provide a selection service similar

${ }^{23}$ Funta, R. (2017) Competition Law Policy and Online-Platforms. EU Law Journal, Vol. 2. No. 1, p. 1 and follows.

24 Zakharchenko, A., Peracek, T., Fedushko, S., Syerov, Y., Trach, O. (2021) When factchecking and 'bbc standards' are helpless: 'fake newsworthy event' manipulation and the reaction of the 'high-quality media' on it. Sustainability, 13 (2), 573.; Peracek, T., Fedushko, S.,Syerov, Y., Trach, O. (2021). Development of methods for the strategic management of web projects. Sustainability, 13 (2), 742. 
to that of journalists, in that search results are ranked. In public, the term gatekeeper is often equated with the term "essential facility". The essential facility's concept states that a company that is dominant in the market because it controls an essential facility can not exploit its position by denying access to the essential facility. ${ }^{25}$ It is doubtful whether search platforms fulfill the legal requirements of an essential facility. This applies regardless of which platform features are examined as essential facilities (user data, web index, search algorithm). It's not surprising that well-known websites, which make up a large part of Internet traffic, are not dependent on search engines. The example of Wikipedia shows, however, that despite relative awareness, a primarily information-gathering website is mainly driven by search engines. Users seem to start their search for information on a search engine in order to find out more from Wikipedia. In addition to search engines there are other frequently ways to visit websites. Display advertising, e-mails or social networks seem to play a subordinate role when it comes to getting to a website. There can be various reasons, such as the lack of brand awareness of a website or the regularity with which certain websites are used. From the perspective of the advertisers, it seems unclear whether a single search engine with a very high market share is a gatekeeper. Against such an assumption we can suggest that there are variety of other websites that provide advertising space on the Internet. There are good reasons against the assumption that search engines like Google or Bing fulfill the requirements of an essential facility. Search engines can only partially be seen as gatekeepers for access to information and users on the Internet. Compared to many other media, the Internet is characterized by its unrestricted access to information. Unlike journalistic gatekeeping, content that does not appear at the top of the search results is basically still accessible to Internet users through other search engines.

\subsubsection{EXPANSION TENDENCIES OF SEARCH PLATFORMS}

As stated earlier, horizontal search engines are multi-side platforms ${ }^{26}$ whose business models are designed to include all relevant platform sides. Search platforms compete with the quality of their search services provided to users. These are in turn a prerequisite for making the platform attractive

${ }^{25}$ Funta, R. (2011) Abuse of a dominant position in EU and US Law. 2. Edition, Brno: Tribun EU, p. 115 and follows.

26 Šmeikal, V. (2016) Výzvy pro evropský antitrust ve světě vícestranných online platforem [Challenges for European antitrust in a world of multilateral online platforms]. In. Antitrust: Revue soutěžního práva, č. 4. pp. 105-114. 
to advertisers and generating revenue. The retrievability of web pages influences the attractiveness of the search service for users. At the same time, content providers benefit from being found. The fact that users and advertisers tend to be less loyal than other platform services (e.g. social networks) to a specific search platform means that the attractiveness of search platform is of decisive importance from the user's point of view and explains why search platforms with high market share have an interest in further developing their offer to secure their market position. At the same time, search platforms as profit-oriented companies face the challenge of opening up new revenue opportunities. Against this background, various strategies ${ }^{27}$ can be identified: the integration of the search service into other software and device platforms, such as browsers and mobile devices, to expand the user base, the integration of new services such as map and message services to increase platform attractiveness and the preference for on-board profit maximization services.

\section{A NEED FOR (NEW) REGULATORY MEASURES?}

We are of the opinion that a purely preventive regulation, in particular through regulation of the search algorithm, is currently not to be advocated. Regulatory measures that would allow search platforms to provide similar access to user data outweigh their perceived risks over the potential benefits. In order to counteract the potential fear of favoring one's own services when displaying search results, it is proposed to prevent preference of one's own services in the presentation of search results by the unbundling of general search services. Any regulatory instruments would have to be proportionately designed and applied in relation to the economic objective. In addition, unbundling could undermine rationalization advantages on the part of the search engine, and existing economies of scale and scope could be lost. In our view, unbundling of a dominant search platform due to the severity of the interference in the business model should be considered if the relevant search platform has a huge market power. Regulation of the search algorithm to ensure search neutrality would require changes to the algorithm. Given the frequency with which changes are made, this would require considerable effort. In addition, due to the complexity of search algorithm,

27 Schweitzer, H., Haucap, J., Kerber, W., Welker, R. (2018) Modernizing the Law on Abuse of Market Power. Report for the Federal Ministry for Economic Affairs and Energy (Germany). p. 4. 
it would be unclear whether a distortion could be objectively determined. The European Commission has pointed out in its Digital Agenda ${ }^{28}$ that technical interoperability and the resulting open architecture of the Internet is a prerequisite for the full use of information and communication technologies.

\subsection{NEW RULES FOR ONLINE PLATFORMS AND SEARCH ENGINES IN THE EU ("P2B REGULATION")}

On June 20, 2019, the EU adopted Regulation (EU) 2019/1150 of the European Parliament and of the Council of 20 June 2019 on promoting fairness and transparency for business users of online intermediation services ("P2B Regulation"). The "P2B Regulation" is the first direct regulation of online platforms by the EU. The "P2B Regulation" applies $^{29}$ to online intermediation services and search engines anywhere in the world that provide services to business users in the EU. The "online intermediation services" include e-commerce marketplaces (e.g. Amazon Marketplace, eBay), online software application services (e.g. Google Play, Apple App Store, Microsoft Store), online social media services (e.g. Facebook, Instagram) or online search engines (e.g. Google search, Bing). But, it does not distinguish between so called large (or gatekeeper) platforms and other platforms. The reason for such platform rules can be found in its recitals which states, that "online intermediation services are key enablers of entrepreneurship and new business models, trade and innovation" (recital 1) that "can be crucial for the commercial success of undertakings who use such services to reach consumers" (recital 2). The "P2B Regulation" should generate indirect benefits for consumers. Thus, its objectives is to (a) ensure fair, transparent and predictable treatment of business users by online platforms; (b) provide more effective redress options and ultimately (c) create a predictable and innovation-friendly regulatory environment for online platforms. The aim of the "P2B Regulation" is that platforms commit to more transparency and fairness: e.g. through disclosure of ranking parameters (Article 5) which are most important for determining the ranking.

28 European Commission, A Digital Agenda for Europe, Communication of 19 May 2010 to the European Parliament, the Council, the European Economic and Social Committee and the Committee of the Regions, COM (2010) 245 final, p. 17 and follows.

29 On the other hand, the P2B Regulation does not apply to online payment services or to online advertising tools or online advertising exchanges, which are not provided with the aim of the facilitating the initiation of direct transactions and which do not involve a contractual relationship with consumers (Article 1(3)). Online payment services (e.g. PayPal) and online advertising tools are thus excluded from the P2B Regulation scope. 
This should help commercial users to understand how the offered goods and/or services are highlighted; through the design of general terms and conditions (Article 3, 6) which should be clear, understandable and available to commercial users before to conclusion of the contract; or through access to data (Article 9) meaning, to disclose the extent to which they have access to the data. The reason why the "P2B Regulation" was adopted comes also from recent EU antitrust cases, such as Google Shopping ${ }^{30}$, where Google was found to have abused its dominance in the search engine market by favoring its own comparison shopping service. This was seen by the European Commission as anti-competitive expansion of dominance from the primary markets for general search services to the secondary markets for comparison shopping services.

\section{CONCLUSIONS}

The Internet enables the development and differentiation of business models. Any barriers to entry resulting in the development of innovative business models over time must be accepted only to the extent that they can be further legally justified. Due to the associated reduction in transaction costs, the economy can meet the demand for goods and services in an increasingly individualized manner. Likewise, consumers themselves can become providers of goods and services on the Internet and via the Internet in other sectors of the economy. The Internet opens up new dimensions of competition (expands markets by enabling consumers to take advantage of every offer available on the internet). ${ }^{31}$ In addition, competition between Internet-based and non-Internet-based goods and services is becoming increasingly competing. For competition policy, the particular characteristics of multi-side platforms are a challenge. The fundamental relationships and complexity of multi-side platforms need to be considered by competition authorities and courts. It is important to include all sides of a platform in the analysis and to record their economic significance. Also the importance of data for the economic success of companies should be given more consideration in competition law assessments. An obligation to publish the search algorithm is not to be advocated. Also an obligation to disclose or split the web index with

AT.39740, Google Search Shopping (2017), 27 June.

31 Šramel, B., Horváth, P. (2021) Internet as the communication medium of the 21st century: do we need a special legal regulation of freedom of expression on the internet? The Lawyer Quarterly. no. 1, pp. 141-157. 
competing search engines is not to be endorsed as it would eliminate incentives to create and constantly update the index. The above mentioned "P2B Regulation" may be seen as a starting point for a platform-specific intervention to target unfair practices which mostly result from the dependence of businesses on platforms. Even the "P2B Regulation" is quite descriptive, there are several aspects which remain unclear, e.g. the "P2B Regulation" does not speak about legal consequences in case of its violation; or the "P2B Regulation" states in Article 1 that it "shall not affect national civil law, in particular contract law". In this perscpective it will be interesting to see how this will correlate with existing national law. Although the "P2B Regulation" can be seen as a step in the right direction in ensuring fairness and transparency, the ex ante regulatory framework does not address the potentially unfair trading practices of some online platforms. The design and application of competition rules in regards to Internet markets will be an interesting area for further research. It would be needed to further monitor and investigate this sector of business in order to understand the impact of these developments and to find out to what extent a more far-reaching regulatory measures for differentiated treatment would be needed in the future.

\section{LIST OF REFERENCES}

[1] Borchardt, K. D. (2010) Die Rechtlichen Grundlagen der Europäischen Union. 4. Auflage, Heidelberg: C. F. Müller.

[2] Commission decision of 27 June 2017 in Case 38606 -AT.39740Google Search (Shopping).

[3] Crémer, J., de Montjoye, Y-A., Schweitzer, H. (2019) Competition Policy for the Digital Era. Brussels: Directorate-General for Competition.

[4] Daňko, M., Žárská, P. (2019) Data protection vs. Intellectual property. Počítačové právo, UI, ochrana údajov a najväčšie technologické trendy. Brno: MSD.

[5] European Commission, A Digital Agenda for Europe, Communication of 19 May 2010 to the European Parliament, the Council, the European Economic and Social Committee and the Committee of the Regions, COM (2010) 245 final.

[6] Funta, R. (2019) Úvod do počítačového práva práva [Introduction into computer law]. Brno: MSD.

[7] Funta, R. (2019) Economic and Legal Features of Digital Markets. In. Danube Law and Economic review, Issue 2. 
[8] Funta, R. (2018) „Big Data“ from competition law point of view. Justičná revue, č. 8-9.

[9] Funta, R. (2018) Facebook from competition law perspective. Justičná revue, č. 1.

[10] Funta, R. (2018) Google Android from legal perspective. Justičná revue, č. 4.

[11] Funta, R. (2018) Amazon and antitrust enforcement. Justičná revue, č. 11.

[12] Funta, R. (2017) Competition Law Policy and Online-Platforms. EU Law Journal, Vol. 2. No. 1.

[13] Funta, R., Nebeský, Š., Juriš, F. (2012) Európske právo [EU law]. Brno: Tribun EU.

[14] Funta, R. (2011) Abuse of a dominant position in EU and US Law. 2. Edition, Brno: Tribun EU.

[15] Furman, J. (2019) Unlocking digital competition. Report of the Digital Competition Expert Panel. London: HM Treasury.

[16] Hudecová, I., Cyprichová, A., Makatura, I. a kol. (2018) Nariadenie o ochrane fyzických osôb pri spracúvaní osobných údajov - Vel'ký komentár. [Regulation on the protection of individuals with regard to the processing of personal data - Commentary], Bratislava: Eurokódex.

[17] Jones, A., Suffrin, B. (2016) EU Competition Law: Text, Cases, and Materials. Oxford: Oxford University Press.

[18] Karas, V., Králik, A. (2012) Právo Európskej únie [European union law]. 1. vydanie, Bratislava: C.H.Beck.

[19] Klimek, L. (2013) Effective Enforcement of Sanctions for Market Abuse in the EU: Introduction of Criminal Sanctions. Czech Yearbook of International Law, New York: Juris Publishing.

[20] Krausová, A. (2018) Abuse of market power in ICT sector. The Lawyer Quarterly, No. 1.

[21] Mesarčík, M. (2020) Ochrana osobných údajov [Personal data protection]. Bratislava: C..H.Beck.

[22] Míšek, J. (2020) Moderní regulatorní metody ochrany osobních údajů. [Modern regulatory methods of personal data protection]. 1. vyd. Brno: Masarykova univerzita.

[23] Peráček, T., Fedushko, S., Syerov, Y., Trach, O. (2021) Development of methods for the strategic management of web projects. Sustainability, 13 (2).

[24] Peráček, T. (2020) The perspectives of European society and the European cooperative as a form of entrepreneurship in the context of the impact of European economic policy. Online Journal Modelling the New Europe, (34).

[25] Polčák, R. a kol. (2018) Právo informačních technologií [Information technology law]. Praha: Wolters Kluwer. 
[26] Plavčan, P.; Funta, R. (2020) Some Economic Characteristics of Internet Platforms. Danube: Law, Economics and Social Issues Review. No. 2.

[27] Schweitzer, H., Haucap, J., Kerber, W., Welker, R. (2018) Modernizing the Law on Abuse of Market Power. Report for the Federal Ministry for Economic Affairs and Energy (Germany).

[28] Svák, J. (2011) Ochrana l’udských práv [Protection of human rights]. I. Zväzok, Bratislava: Eurokódex.

[29] Svoboda, P. (2010) Úvod do Evropského práva [Introduction into EU law]. 3. vydání, Praha: C.H.Beck.

[30] Svoboda, P., Munková, J., Kindl, J. (2012) Soutěžní právo [Competition law]. 2. vydání, Praha: C.H.Beck.

[31] Šmejkal, V. (2016) Výzvy pro evropský antitrust ve světě vícestranných online platforem [Challenges for European antitrust in a world of multilateral online platforms]. In. Antitrust: Revue soutěžního práva, č. 4.

[32] Šramel, B., Horváth, P. (2021) Internet as the communication medium of the 21st century: do we need a special legal regulation of freedom of expression on the internet? The Lawyer Quarterly. No. 1.

[33] Zakharchenko, A., Peráček, T., Fedushko, S., Syerov, Y. \& Trach, O. (2021) When factchecking and 'bbc standards' are helpless: 'fake newsworthy event' manipulation and the reaction of the 'high-quality media' on it. Sustainability, 13 (2). 